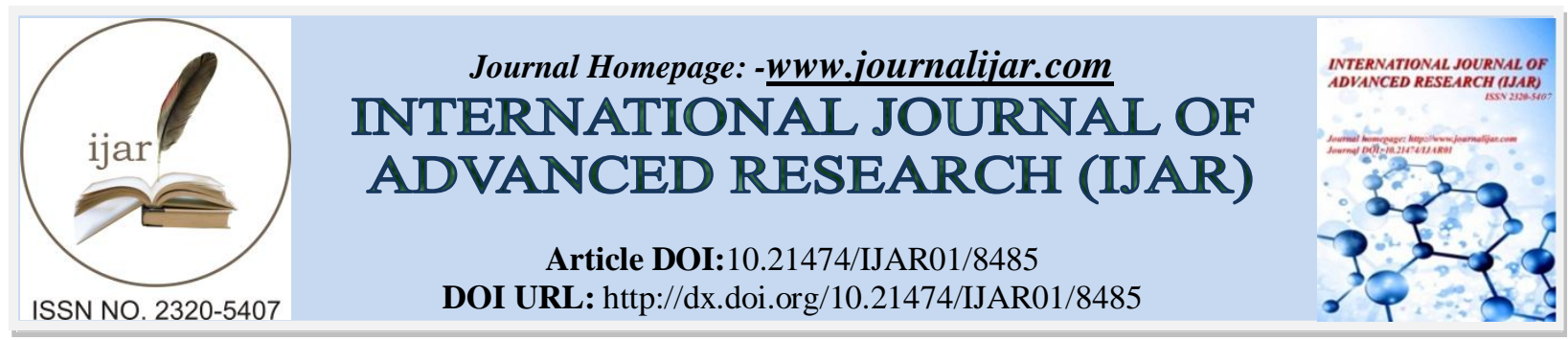

RESEARCH ARTICLE

\title{
PREVALENCE OF PLASMID MEDIATED AMINOGLYCOSIDE MODIFYING ENZYMES IN PSEUDOMONAS AERUGINOSA IN HOSPITALIZED PATIENTS AT A TERTIARY CARE CENTRE.
}

Santanu Hazra ${ }^{1}$, Partha Roy ${ }^{2}$ and Anubha Patel ${ }^{1}$.

1. Resident, Department of Microbiology, Armed Forces Medical College, Pune 411040, India.

2. Senior Consultant (Microbiology and Virology), Oncquest Laboratories Limited, New Delhi 110029, India.

\section{Manuscript Info}

Manuscript History

Received: 02 December 2018

Final Accepted: 04 January 2019

Published: February 2019

Key words:-

Pseudomonas aeruginosa, Kirby-Bauer disc diffusion method, Aminoglycoside, Aminoglycoside Modifying enzyme, Multiplex PCR.

\section{Abstract}

Background:-Pseudomonas aeruginosa is an important cause of hospital-acquired infection. It is frequently recovered species from clinical specimens and multidrug-resistant are increasingly being reported worldwide. In spite of high resistance, aminoglycosides are still an important treatment option in infection with P. aeruginosa. The major factor responsible for aminoglycoside resistance is Aminoglycoside-modifying enzymes (AMEs), carried by mobile genetic elements.

Aim: The study was conducted to determine the prevalence of plasmidmediated AME coding genes in $P$. aeruginosa.

Methods: One hundred and forty consecutive, non-repeat isolates of $P$. aeruginosa were collected from various clinical samples. Sensitivity to amikacin, gentamicin, netilmicin, and tobramycin were detected by Kirby-Bauer disc diffusion method. AMEs-coding genes were detected by the molecular method.

Result: Out of the 140 isolates, $62.14 \%$ were resistant to amikacin, $80 \%$ to gentamicin, $77.86 \%$ to netilmicin and $72.86 \%$ to tobramycin. $77.14 \%$ isolates were found to carry AMEs-coding genes. aac(6')-I was the most frequently encountered gene $(58.57 \%)$ present either singly or in combinatios, followed by ant(2")-I (50\%) and aph(3')-I (32.14\%).

Conclusions: Markedly high resistance was observed against all aminoglycoside tested along with the high prevalence of AMEs-coding genes. These isolate may represent as potential reservoirs of aminoglycoside resistance in hospitals, having combinations of AMEscoding genes on their plasmids. Good infection control practices and antibiotic stewardship programme are very important to prevent the spread of infections.

Copy Right, IJAR, 2019,. All rights reserved.

\section{Introduction:-}

Hospital-acquired infections (HAI) are a major threat to patients admitted in the acute care units. It is one of the important public health problems around the world. In association with increased morbidity and mortality, HAI is an important cause of prolonged hospital stay, inconvenience to the patients and an economic burden on healthcare. [1] Decreased immunity, increasing numbers of invasive techniques, critical life-saving operations, and immunosuppressive therapies are frequently associated with transmission of drug-resistant bacteria among patients 
in hospitals with poor infection control practice. HAIs are most common in Intensive care units (ICU), acute surgical and orthopedic wards. The most frequent HAIs are infections of surgical wounds, urinary tract infections. Bloodstream infection and infections of lower respiratory tract including ventilator-associated pneumonia (VAP) are also very frequent in hospitalized patients. However, bloodstream infections and lower respiratory tract infections are the most lethal. [2] Enterobacteriaceae family being the most common identifiable groups overall, multidrugresistant organisms, including $P$. aeruginosa are increasingly being reported worldwide and associated with a high mortality rate. $[3,4] P$. aeruginosa are commonly associated with septicemia in burn patients, urinary tract infections in the catheterized patient, surgical site infections and chronic debilitating respiratory infections in cystic fibrosis patients. $[2,4,5]$

In addition being intrinsically resistant to several antimicrobial agents, $P$. aeruginosa can easily develop resistance to all conventional antipseudomonal antibiotics, limiting the choice of effective antibiotics and complicating treatment. $[4,6]$ The aminoglycosides are still very effective in the treatment of infections caused by aerobic gramnegative bacilli, including $P$. aeruginosa. Aminoglycosides act synergistically with other antibiotics active against the cell-wall like the $\beta$-lactam, thus facilitates cell killing and reduces the risk of development of resistance. [6] Infections with $P$. aeruginosa are commonly treated with an aminoglycoside and antipseudomonal penicillin (e.g., Piperacillin) or antipseudomonal cephalosporin (e.g., Ceftazidime). Three mechanisms are responsible for aminoglycoside resistance: alteration of outer membrane permeability or diminished inner membrane transport or active efflux leading to decreased intracellular accumulation; target modification by 16S rRNA mutation or methylation or ribosomal protein-coding gene mutation; enzyme-mediated drug modification [7, 8]. In the clinical setting, Aminoglycoside resistance is mainly due to AMEs causing modification of amino- or hydroxyl groups. This, in turn, reduces or inhibits binding of the aminoglycoside molecule to the ribosome and failure in trigging energydependent phase II. [8] The three main classes of AMEs are aminoglycoside $\mathrm{N}$-acetyltransferases (AACs), aminoglycoside O-phosphotransferases (APHs), and aminoglycoside O-nucleotidyltransferases (ANTs). aac(6')-Ib is most frequently found in $P$. aeruginosa and a major contributor to aminoglycoside resistance. The genes coding for $\operatorname{aac}\left(6^{\prime}\right)$ is often part of mobile genetic elements. aph (3')-I and aph (3')-II are well documented in the clinical specimen of $P$. aeruginosa. [8] The genes encoding the APHs have been found on $\mathrm{R}$ - plasmid, transposons, integrons and responsible for multiple drug resistance. ant (2")-Ia is best known to confer resistance to gentamicin, kanamycin, and tobramycin. It is encoded on the plasmid or integrons in many Gram-negative bacteria, including P. aeruginosa. [8]

However, little is known about the prevalence of these AMEs-coding genes among P. aeruginosa. Our effort in this study was to explore the plasmid-mediated AMEs-coding genes responsible for aminoglycoside resistance in $P$. aeruginosa from clinical isolates.

\section{Materials and Methods:- Isolation \& identification}

This prospective study was carried out from December 2013 to November 2014. One hundred and forty consecutive, non-repeat clinical isolates of $P$. aeruginosa were collected from various clinical samples of hospitalized patients at a tertiary care hospital and were identified by conventional phenotypic methods.

\section{Antimicrobial susceptibility testing}

Isolates were tested for their susceptibility to four aminoglycosides; amikacin, gentamicin, tobramycin, and netilmicin by Kirby-Bauer disc diffusion method. Results were interpreted according to Clinical and Laboratory Standards Institute (CLSI) guidelines, 2014 (M100 - S24). [9]

Isolates resistant to any tested aminoglycosides; amikacin, gentamicin, tobramycin, and netilmicin were defined as aminoglycoside resistant. P. aeruginosa (ATCC 27853) served as a control.

\section{Genotypic Detection of Aminoglycoside Modifying Enzymes}

4-5 colonies of isolate were dissolved in $2 \mathrm{ml}$ Luria Bertani broth. The broth was incubated for 48 hours at $37^{\circ} \mathrm{C}$. Cells were harvested, and Plasmid DNA was extracted by the spin column method (Hi-PURA Plasmid Miniprep, Hi-MEDIA). 
Five AMEs - coding genes, aac (6')-I, aph (3')-I, aac (3)-I, aac (3)-II and ant (2")-I were selected for screening. PCR for detection of the AMEs - coding genes was carried out using five sets of primers, designed from sequence deposited in the GeneBank database (Table 1).

The PCR assay was carried out in a final volume of $25 \mu \mathrm{l}$, containing $12.5 \mu \mathrm{l}$ of 2X Dream TaqTM Green PCR Master Mix (Fermentas, USA), $1 \mu \mathrm{l}$ (25 picomoles) of each primer (Integrated DNA Technologies, IDT), $1 \mu 1$ of plasmid DNA and molecular grade water. Various amplification conditions were used for each primer set. Amplification products were detected by electrophoresis on $1 \% \mathrm{w} / \mathrm{v}$ agarose gel containing $0.5 \%$ ethidium bromide and visualized on UV transilluminator. Amplicon size was determined using ready-to-use 100 bp Plus DNA ladder (Fermentas, USA) run along with samples every time.

\section{DNA Sequencing}

Ten amplicons representative of the two sets of primers were verified by Sanger's capillary sequencing. The nucleotide sequences of the amplicons were analyzed using the open access software of National Center of Biotechnology Information website (http://www.ncbi.nlm.nih.gov).

\section{Results:-}

Out of 140 P. aeruginosa, 48 (34.29\%) were isolated from pus, 26 (18.57\%) from blood, 25 (17.85\%) from tracheal aspirates, $16(11.43 \%)$ from urine, $14(10 \%)$ from tissues and $11(7.86 \%)$ from other samples. (Figure 1)

73 (52.14\%) isolates were obtained from different surgical wards including burn care unit and urology unit. 29 (20.71\%) isolates were obtained from surgical ICU, 21 (15\%) were from medical ICU and 17 (12.14\%) from acute medical units. $117(83.57 \%)$ isolates were obtained from male patients and 23 (16.43\%) from female patients. (Figure 2)

$87(62.14 \%)$ isolates were resistant to amikacin, $112(80 \%)$ to gentamicin, 109 (77.86\%) to netilmicin and 102 (72.86\%) to tobramycin (Table 2).

\section{Prevalence of AMEs-coding Genes}

Among 140 isolates tested, 108 (77.14\%) were found to carry AMEs-coding genes on their plasmid. They were found either singly or in different combinations. $a a c\left(6^{\prime}\right)$-I was the most frequently encountered gene (58.57\%) either singly or in combinations, followed by ant( $\left.2^{\prime \prime}\right)-\mathrm{I}(50 \%)$, aph(3')-I (32.14\%) and aac(3)-II (8.57\%). While aac(3)-I was not detected in any of the isolates. (Figure 3, 4, 5, 6) $33(23.57 \%)$ isolates had only one AME-coding gene. ant (2")-I was the most common single AMEs-coding gene, detected in 19 isolates (13.57\%) followed by aac $\left(6^{\prime}\right)$-I, in $10(7.14 \%)$ isolates. $47(33.57 \%)$ isolates were detected with carrying two genes. ant (2")-I and aac (6')-I combination were detected in $24(17.14 \%)$ isolates, followed by aph (3')-I and aac (6')-I combination in $18(12.86 \%)$ isolates. Coexistence of three AMEs-coding genes was detected in $27(19.29 \%)$ isolates and 1 isolate $(0.7 \%)$ with four AMEs-coding genes. The presence of AMEs-coding genes could not be detected on the plasmids of 13 resistance isolates (9.29\%) despite showing resistance to at least one of the tested aminoglycoside antibiotics. (Table 3)

\section{Discussion:-}

P. aeruginosa is a major pathogenic species in the family Pseudomonadaceae. It is one of the most serious bacterial infection and is responsible for $10 \%$ of HAI. [1,2] It has the considerable potency to become resistant to many antibiotics. Increasingly more antimicrobial resistant strains are being encountered in clinical practice, leaving the treating physician with limited treatment options and severe adverse outcome. $[4,8]$

In the present study, $34.29 \%$ P. aeruginosa was isolated from pus, $18.57 \%$ from blood, $17.85 \%$ from tracheal aspirates, $11.43 \%$ from urine, $10 \%$ from tissues. In another study by Kalaivani R et al. showed the major source of P. aeruginosa was wound (43\%) followed by endotracheal aspirate (19\%), urine (16\%) and blood (11\%). [10] Srinivas B et al. also described the highest isolation rate from pus $(55.35 \%)$ and urine (18.45\%). [11] Study by Arora D et al. showed a major source of $P$. aeruginosa was urine (36\%), followed by wound discharge (20\%). [12]

$52.14 \%$ P. aeruginosa was isolated from different surgical wards followed by surgical ICU (20.71\%), medical ICU (15\%) and other medical wards (12.14\%). Raakhee T et al. showed the highest isolation of $P$. aeruginosa was from 
surgical ICU (26.24\%). [13] Anupurba S et al. also showed an important source of P. aeruginosa was surgical wards (29.9\%) and burn care units (21.7\%). [14]

Among aminoglycosides, $62.14 \%$ isolates were resistant to amikacin, $80 \%$ to gentamicin, $77.86 \%$ to netilmicin and $72.86 \%$ isolates were resistant to tobramycin. In a study done by Upadhyay S et al., resistance rate was $52.5 \%$ to amikacin, $60.9 \%$ to gentamicin and 58.9\% to netilmicin. [15] Shahid M et al. showed high resistance to amikacin (55.1\%) and tobramycin (83.6\%). [16] Arora D et al. also found $41.5 \%$ resistance to amikacin and $79 \%$ to gentamicin. [12]

In present study, $76.43 \%$ isolates were found to carry AMEs. In another study by Chaudhary $\mathrm{M}$ et al., the prevalence of AMEs-carrying genes in P. aeruginosa was $68.92 \%$. [17] aac(6')-I is the most prevalent AMEs -coding gene that specifies resistance to several aminoglycosides and shows high resistance against amikacin and gentamicin. [8] In the present study, 58.57\% isolates were carrying aac(6')-I genes singly or in combination. Similar high prevalence of aac $\left(6^{\prime}\right)$ genes in P. aeruginosa was reported by Shahid M et al. (42.8\%) and Chaudhary $M$ et al. $(43.5 \%)$. [16, 17] The prevalence of ant (2")-I, aph (3')-I and aac (3)-II was 50\%, 32.14\%, and $8.57 \%$ respectively. Chaudhary M et al. showed $18.9 \%$ and $9.4 \%$ prevalence of ant (2") and aph (3) genes among P. aeruginosa. Shahid M et al. reported the prevalence of aph (3')-I and aac (3)-II were $16.3 \%$ and $20.4 \%$ isolates respectively. [16, 17]

Miller et al. reported that in Europe aac(6')-II was the most prevalent followed by ant (2")-I. [18] Whereas, Kim JY et al. from Korea nationwide study on P. aeruginosa observed that $a a c\left(6^{\prime}\right)-\mathrm{I}$ and ant (2")-I were prevalent but none harboured $\operatorname{aac}\left(6^{\prime}\right)$-II. [19]

\section{Conclusion:-}

This study provided information about resistance pattern of different aminoglycosides against $P$. aeruginosa and resistance determinants providing useful comparative data for future study. Because of synergism with other drugs and post antibactericidal effect, aminoglycosides remain useful antipseudomonal agents. However, the high prevalence of plasmid-mediated aminoglycoside resistance in $P$. aeruginosa among hospitalized patients was observed which could easily spread and be disseminated among other bacteria. Proper infection control practices and periodic monitoring of resistance to aminoglycoside antibiotics are required to minimize further dissemination and preserve the usefulness of this important class of antibiotics for the treatment of complicated infection.

\section{Conflict of interest:}

None

\section{Funding:}

This research did not receive any specific grant from funding agencies in the public, commercial, or not-for-profit sectors.

\section{Ethical approval:}

Not required

\section{Legends for figures:-}

Figure 1:-Sample wise distribution of isolates.

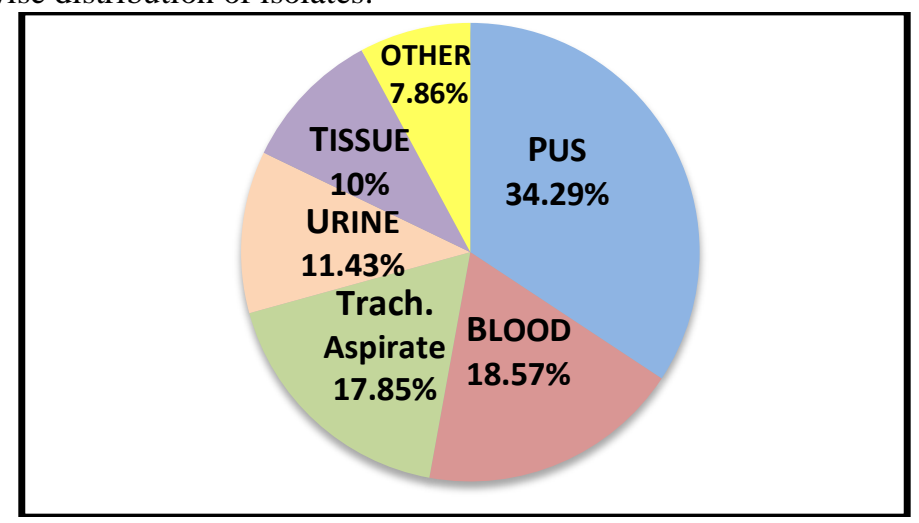


Figure 2:-Source wise distribution of isolates

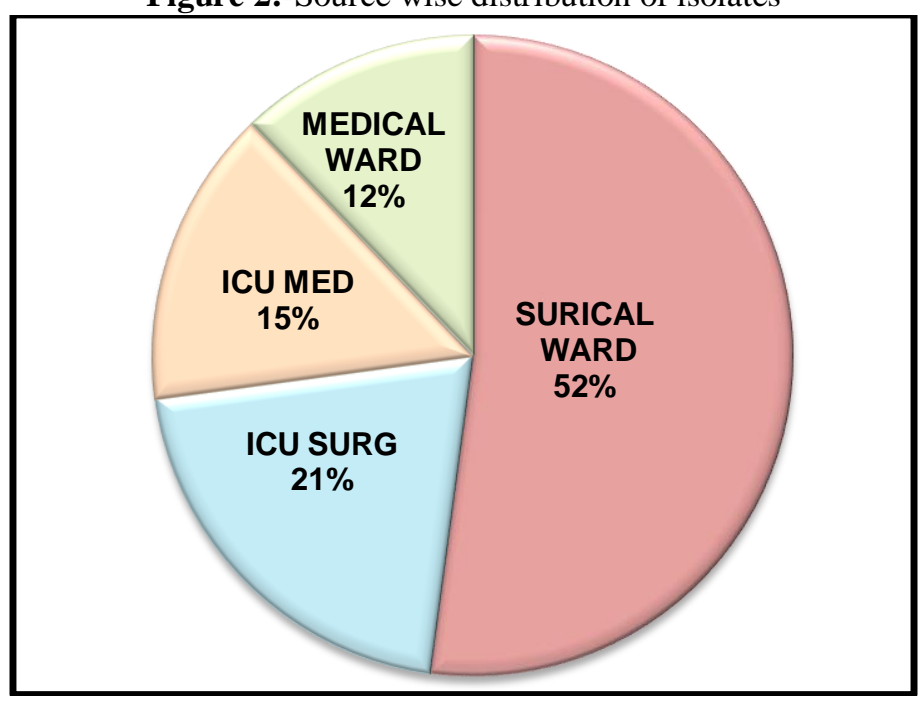

Figure 3:-Post-amplification 2\% gel electrophoresis ant (2")-I (288bp)

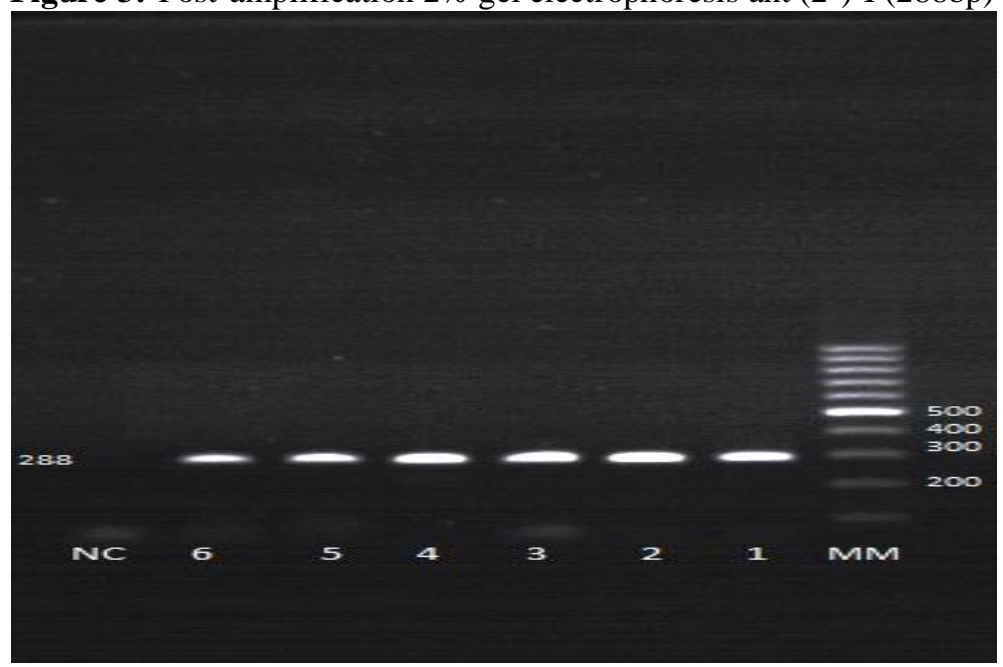

Figure 4:-Post-amplification2\% gel electrophoresis aph (3')-I (223bp), aac(6')-I (356bp), aac (3)-II (567 bp).

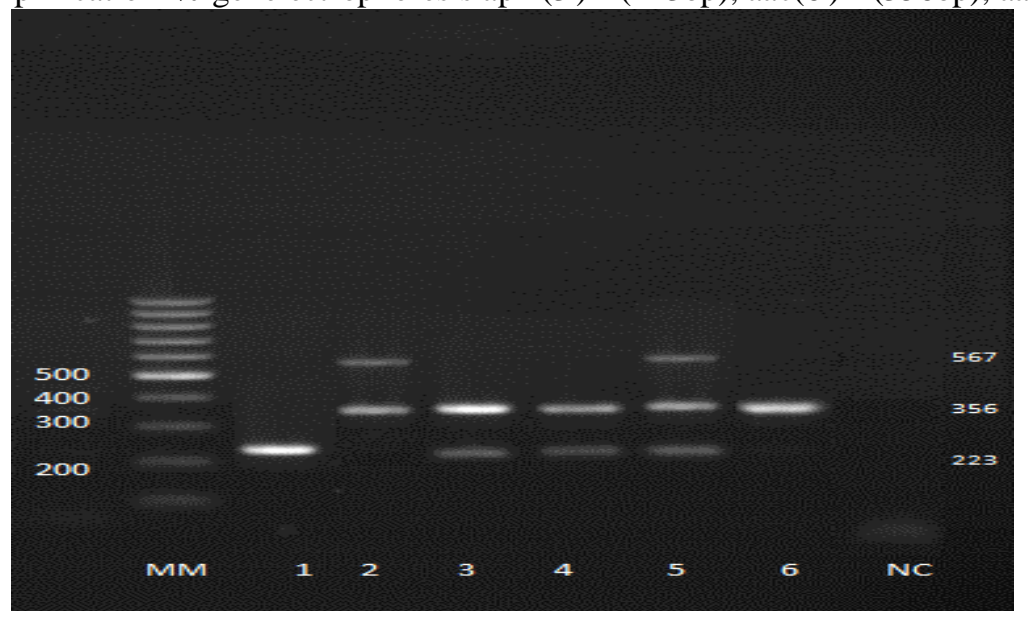


Figure 5:-DNA sequence on capillary sequencing (Sanger's Method)

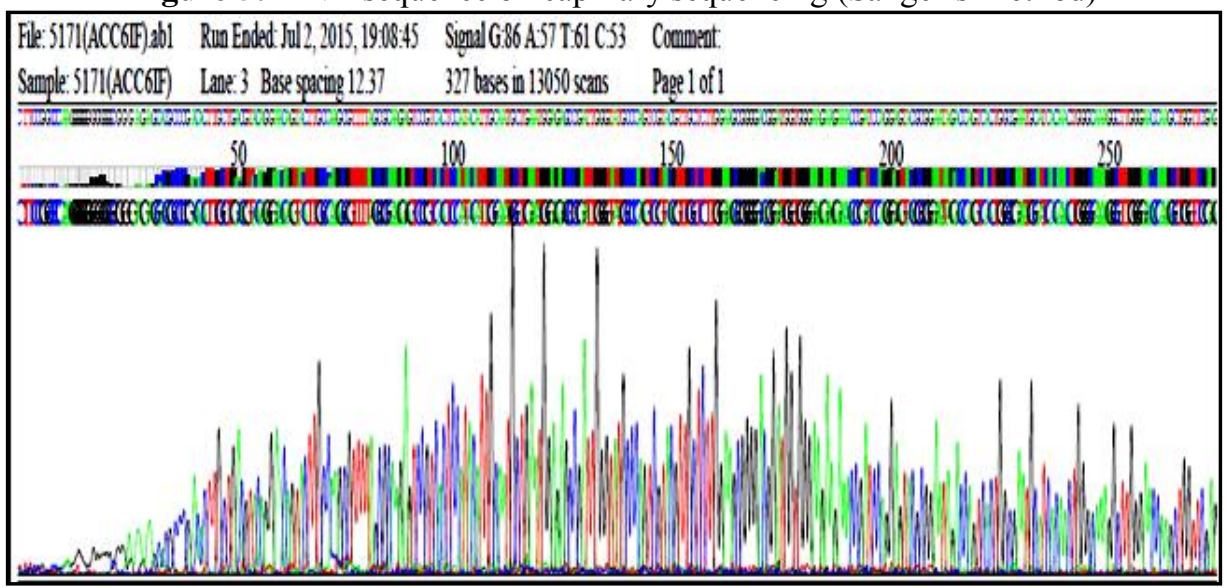

Figure 6:-Nucleotide sequence BLAST on NCBI site.

\begin{tabular}{|l|lcl|}
\hline \multicolumn{4}{|l|}{$\begin{array}{l}\text { Pseudomonas aeruginosa strain Ps398 class } 1 \text { integron In1160, partial sequence } \\
\text { Sequence ID: gb|KR } 184824.1\end{array}$} \\
Range $1: 590$ to 944
\end{tabular}

Table 1:-List of Primers

\begin{tabular}{|c|c|c|c|}
\hline Primer & Primer sequences $\left(5^{\prime}-3^{\prime}\right)$ & $\begin{array}{l}\text { Target } \\
\text { genes }{ }^{\text {a }}\end{array}$ & $\begin{array}{l}\text { Amplicon size } \\
\text { (bp) }\end{array}$ \\
\hline $\begin{array}{l}\text { APH(3')I-f } \\
\text { APH(3')I-r }\end{array}$ & $\begin{array}{l}\text { TTATGCCTCTTCCGACCATC } \\
\text { GCCTGAGCGAGACGAAATAC }\end{array}$ & $\begin{array}{l}\text { aph (3')- } \\
\text { Ia/ aph } \\
\left(3^{\prime}\right)-\text { Ic }\end{array}$ & 223 \\
\hline $\begin{array}{l}\text { AAC (6')I-f } \\
\text { AAC(6')I-r }\end{array}$ & $\begin{array}{l}\text { TTGCGATGCTCTATGAGTGG } \\
\text { CGTTTGGATCTTGGTGACCT }\end{array}$ & $\begin{array}{l}\text { aac (6')- } \\
\mathrm{Ib} / \\
\text { (aacA4) }\end{array}$ & 356 \\
\hline $\begin{array}{l}\operatorname{AAC}(3) \mathrm{I}-\mathrm{f} \\
\operatorname{AAC}(3) \mathrm{I}-\mathrm{r}\end{array}$ & $\begin{array}{l}\text { CCACCTACTCCCAACATCA } \\
\text { TTCCCGTATGCCCAACTTT }\end{array}$ & $\begin{array}{l}\text { aac (3)-I/ } \\
\text { (aacC1) }\end{array}$ & 329 \\
\hline $\begin{array}{l}\text { AAC(3)II -f } \\
\text { AAC(3)II-r }\end{array}$ & $\begin{array}{l}\text { GCAGAAGGCAATAACGGAG } \\
\text { CCAGGCATCGGCATCTCATA }\end{array}$ & $\begin{array}{ll}\text { aac } & \text { (3)- } \\
\mathrm{IIa} / & \\
\text { aac } & (3)- \\
\mathrm{IIc} & \\
\end{array}$ & 567 \\
\hline $\begin{array}{l}\text { ANT(2")I-f } \\
\text { ANT(2")I-r }\end{array}$ & $\begin{array}{l}\text { AAGCACGATGATATTGATCTG } \\
\text { GGCATAGTAAAAGTAATCCCA }\end{array}$ & $\begin{array}{l}\text { ant (2")- } \\
\mathrm{Ia} / \\
(\mathrm{aadB})\end{array}$ & 288 \\
\hline
\end{tabular}

f: forward primer, r: reverse primer

${ }^{a}$ Alternate names of target genes as described by Ramirez et al [8]

Table 2:-Antimicrobial sensitivity pattern against aminoglycosides. 


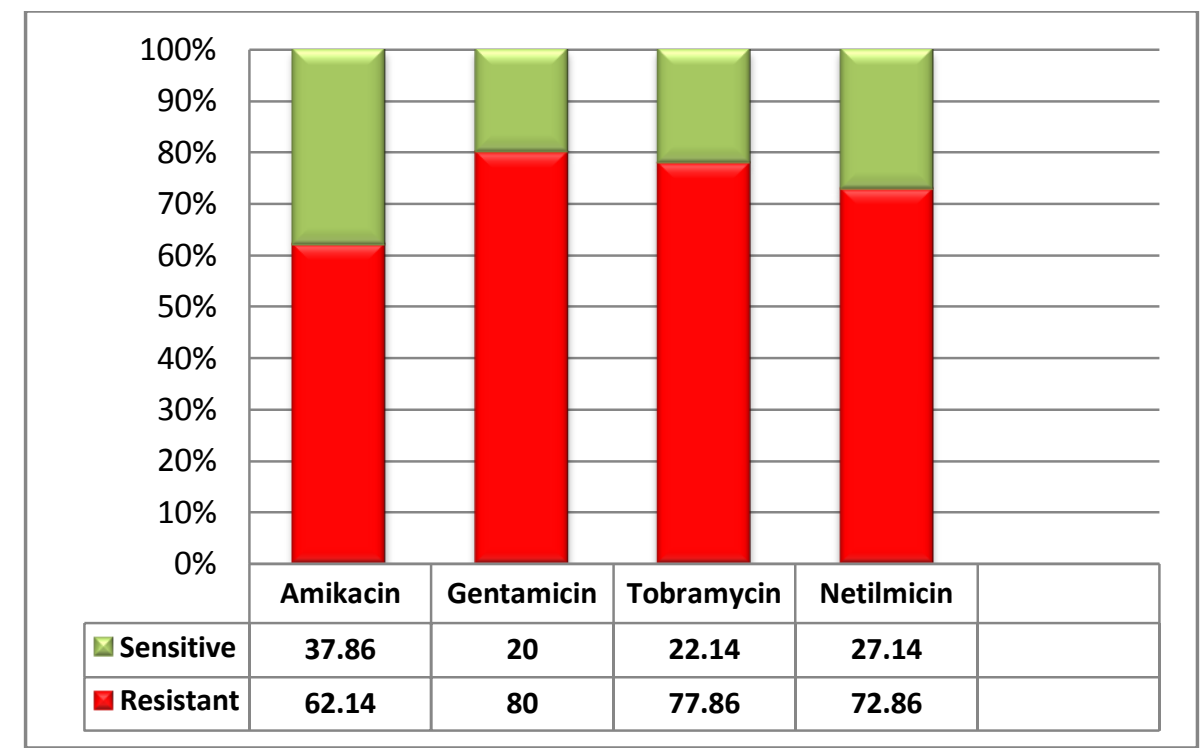

Table 3:-Distribution of AME Coding Genes

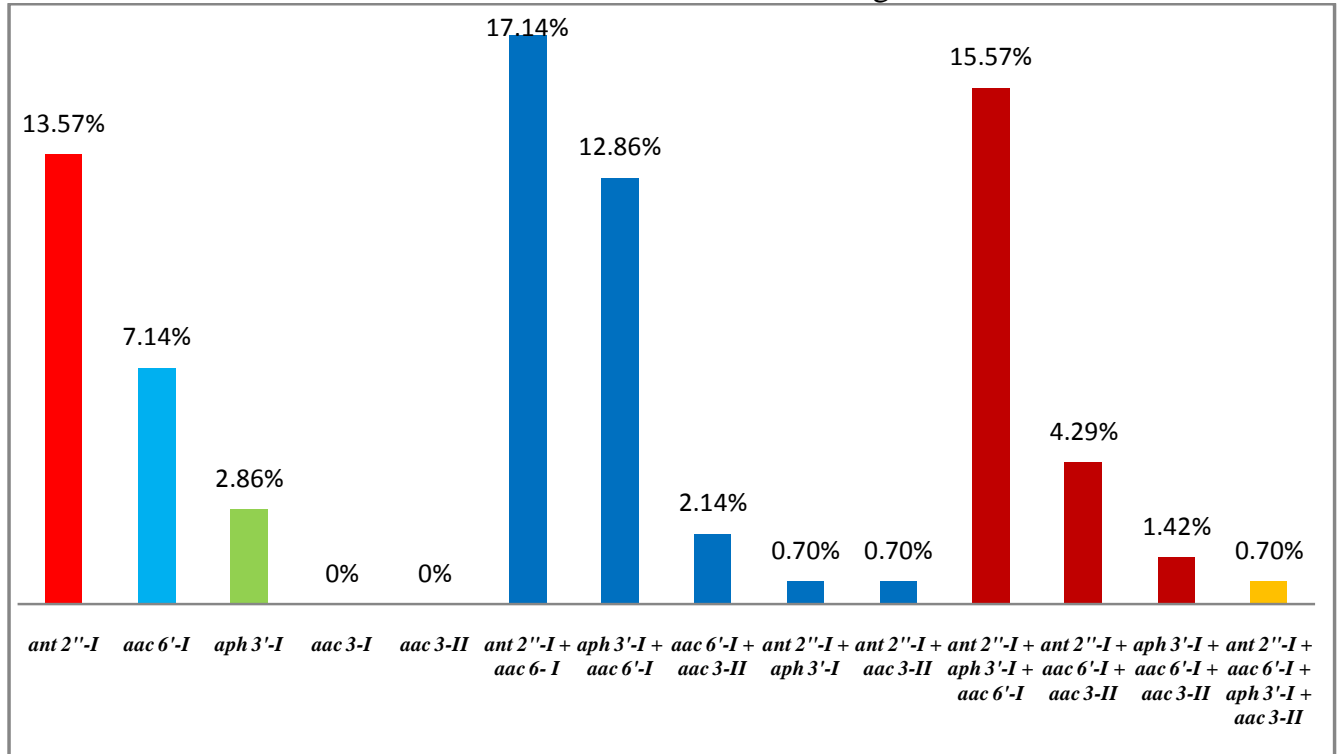

\section{References:-}

1. Malhotra S, Sharma S, Hans C. Prevalence of Hospital Acquired Infections in a tertiary care hospital in India. Int. J. Med. Med. Sci. 2014; 1(7): 91 - 94.

2. Tikhomirov E. WHO Programme for the Control of Hospital Infections. Chemiotherapia. 1987; 3:148-151.

3. Hidron AI, Edwards JR, Patel J et al. NHSN annual update: Antimicrobial-resistant pathogens associated with healthcare-associated infections: Annual summary of data reported to the national healthcare safety network at the centers for disease control and prevention, 2006-2007. Infect Control Hosp Epidemiol. 2008; 29 (11): 9961011.

4. Kerr KG, Snelling AM. Pseudomonas aeruginosa: a formidable and ever-present adversary. J Hosp Infect. 2009; 73: 338-344.

5. Hill D, Rose B, Pajkos A, Robinson M, Bye P, Bett S et al. Susceptibilities of Pseudomonas aeruginosa isolates derived from patients with cystic fibrosis under aerobic, anaerobic, and biofilm conditions. J Clin Microbiol. 2005; 43 (10): $5085-5090$. 
6. Rossolini GM, Mantengoli E. Treatment and control of severe infections caused by multiresistant Pseudomonas aeruginosa, Clin Microbiol Infect. 2005; 11, 17 - 32.

7. Shaw KJ, Rather PN, Hare RS, Miller GH. Molecular genetics of aminoglycoside resistance genes and familial relationships of the aminoglycoside-modifying enzymes. Microbiol Rev. 1993;57(1):138-63.

8. Ramirez MS, Tomalski ME. Aminoglycoside modifying enzyme. Drug Resistance Update. 2010; 13: 151 171.

9. M100 - S24. Performance standards for antimicrobial susceptibility testing; twenty - fourth informational supplement. Clinical and laboratory standards institute. January 2014.

10. Kalaivani R, Shashikala P, Sheela Devi C, Prashanth K, Saranathan R. Phenotypic assays for detection of ESBL and MBL producers among the clinical isolates of multidrug resistance Pseudomonas aeruginosa from a tertiary care hospital. Int J Cur Rev. 2013; 5 (17): 28 - 35.

11. Srinivas B, Lalitha Devi D, Narasinga Rao B. A prospective study of Pseudomonas aeruginosa and its antibiogram in a teaching hospital of rural setup. J Pharm Biomed Sci. 2012; 22 (18): $1-5$.

12. Arora D, Jindal N, Kumar R, Romit. Emerging antibiotic resistance in Pseudomonas - A challenge. Int J Pharm Pharm Sci.2011; 3 (2): $82-84$.

13. Raakhee T, Sreenivasa Rao U. Prevalence and resistance of Pseudomonas strains isolated from ICU patients. Int J Curr Microbiol App Sci. 2014; 3 (3): 527 - 534.

14. Anupurba S, Bhattacharjee A, Garg A, Sen M R. Antimicrobial susceptibility of Pseudomonas aeruginosa isolated from wound infection. Indian J Dermatol. 2006; 51 (4): 286 - 288.

15. Upadhyay S, Sen M R, Bhattacharjee A. Presence of different beta - lactamase classes among clinical isolates of Pseudomonas aeruginosa expressing AmpC beta-lactamase enzyme. J Infect Dev Ctries. 2010; 4 (4): 239 242.

16. Shahid M, Malik A. Resistance due to aminoglycoside modifying enzymes in Pseudomonas aeruginosa isolates from burn patients. Indian J Med Res. 2005; 122: 324 - 329.

17. Chaudhary M, Payasi A. Resistance patterns and prevalence of the aminoglycoside modifying enzymes in clinical isolates of gram negative pathogens. Global J. Pharmacol. 2014; 8 (1): 73 - 79.

18. Miller GH, Sabatelli FJ, Hare RS, Glupczynski Y, Mackey P, Shlaes D, et al. The most frequent aminoglycoside resistance mechanisms changes with time and geographic area: a reflection of aminoglycoside usage patterns. Clin Infect Dis. 1997; 24: 46-62.

19. Kim JY, Park YJ, Kwon HJ, Han K, Kang MW, Woo GJ. Occurrence and mechanisms of amikacin resistance and its association with b-lactamases in Pseudomonas aeruginosa: a Korean nationwide study. J Antimicrob Chemother. 2008; 62: 479-83. 